\title{
Kajian Pertumbuhan Ikan Tembakang (Helostoma temminckii) Di Rawa Bawang Latak Kabupaten Tulang Bawang, Lampung
}

\section{Growth Study of Fish Tembakang (Helostoma temminckii) In Rawa Bawang Latak Tulang Bawang, Lampung}

\author{
Bintang Ubamnata ${ }^{1}$, Rara Diantari ${ }^{2}$, dan Qadar Hasani ${ }^{2}$, \\ ${ }^{1}$ Jurusan Budidaya Perairan Universitas Lampung. \\ ${ }^{2}$ Dosen Jurusan Budidaya Perairan Universitas Lampung. \\ Jln. Prof. Soemantri Brodjonegoro No. 1 Raja Basa, Bandar Lampung. \\ Korespondensi: Ubamnata.bintang@yahoo.com
}

\begin{abstract}
Tembakang Fish (Helostoma temminckii) is one of the fish that have high economic value in Rawa Bawang Latak. Overfishing and the introduction of fish resulted tembakang number of fish populations decline, so it takes the efforts of domestication. This study aims to determine the growth pattern that includes tembakang fish length and weight relationships, growth parameters, and factor conditions. Research carried out for four months, ie in October 2013 - January 2014. Tembakang fishing done at two stations in Rawa Bawang Latak. The sampling frequency of fish is done only once a month using Sero. The results showed that the pattern of growth tembakang fish is allometric positive, condition factor values male and female fish were not significantly different, female tembakang fish growth faster than the male fish, fish tembakang males on the size of $180.6 \mathrm{~mm}$ was 21 months, while females in size $191.1 \mathrm{~mm} 8$ months old.
\end{abstract}

Keywords: Tembakang, Growth, Sero, Rawa Bawang Latak.

Diterima: 10-12-2014 disetujui 07-02-2015

\section{PENDAHULUAN}

Kabupaten Tulang Bawang memiliki daerah aliran sungai yang luas \pm 100 Ha. Salah satu daerah aliran sungai yang menjadi habitat banyak jenis ikan adalah Rawa Bawang Latak. Rawa Bawang Latak merupakan daerah aliran sungai yang berasal dari Sungai Miring di daerah Kotabumi Lampung Utara dan Sungai Bakung di daerah Kabupaten Lampung Tengah, yang melewati Kabupaten Tulang Bawang, Kota Menggala, hingga bermura ke Sungai Tulang Bawang.

Rawa Bawang Latak mempunyai potensi berbagai jenis ikan yang memiliki nilai ekonomis yang cukup tinggi, salah satunya adalah ikan tembakang (Helostoma temminckii). Ikan ini biasa disebut dengan kissing gurame, karena bentuk tubuhnya mirip dengan ikan gurame. Ikan ini dimanfaatkan oleh masyarakat diantaranya sebagai bahan pakan untuk ikan pada keramba jaring apung, namun telur ikan tembakang (Helostoma temminckii) dimanfaatkan dalam acara adat Lampung untuk pemberian bekal keberangkatan haji. Hal ini yang menyebabkan telur ikan tembakang menjadi mahal, harganya mencapai Rp 250.000/Kg. 
Penurunan populasi ikan tembakang tidak terlepas dari penangkapan oleh nelayan. Hasil tangkapan merupakan bagian penting bagi nelayan, tidak jarang ikan yang sedang matang gonad ikut tertangkap, sehingga ikan tidak dapat memijah, ini yang dimaksud dari penangkapan yang tidak terkendali yang menyebabkan populasi suatu jenis ikan dapat menurun.

Selain penangkapan oleh nelayan, penambahan keanekaragaman jenis ikan pada suatu perairan yang bukan berasal dari habitat perairan tersebut mungkin dapat menjadikan ikan-ikan spesies baru tersebut sebagai kompetitor atau bahkan predator yang serius bagi ikan-ikan endemik pada suatu perairan. Apalagi jika ikan-ikan spesies baru yang dimasukkan memiliki daya tumbuh kembang yang sangat cepat. Hal ini sangat memungkinkan ikan introduksi ini menjadi ancaman serius bagi ikan-ikan endemik, yang mungkin saja memiliki daya tumbuh kembang yang jauh lebih rendah dibandingkan ikan-ikan spesies baru yang dimasukkan pada perairan tersebut (Anonim, 2011).

Tujuan penelitian ini adalah untuk mengkaji beberapa parameter, dan pola pertumbuhan ikan tembakang yang meliputi hubungan panjang dan berat, parameter pertumbuhan, dan faktor kondisi. Kajian tersebut kemudian dapat menjadi dasar informasi untuk melakukan domestikasi ikan tembakang sehingga dapat menambah keragaman jenis ikan budidaya.

\section{METODE}

Penelitian ini dilaksanakan dilaksanakan selama 4 bulan, dimulai dari bulan Oktober 2013 hingga Januari 2014. Pengambilan sampel dilakukan di Rawa Bawang Latak, Desa Ujung Ilir, Kecamatan Menggala Kota, Kabupaten Tulang Bawang.

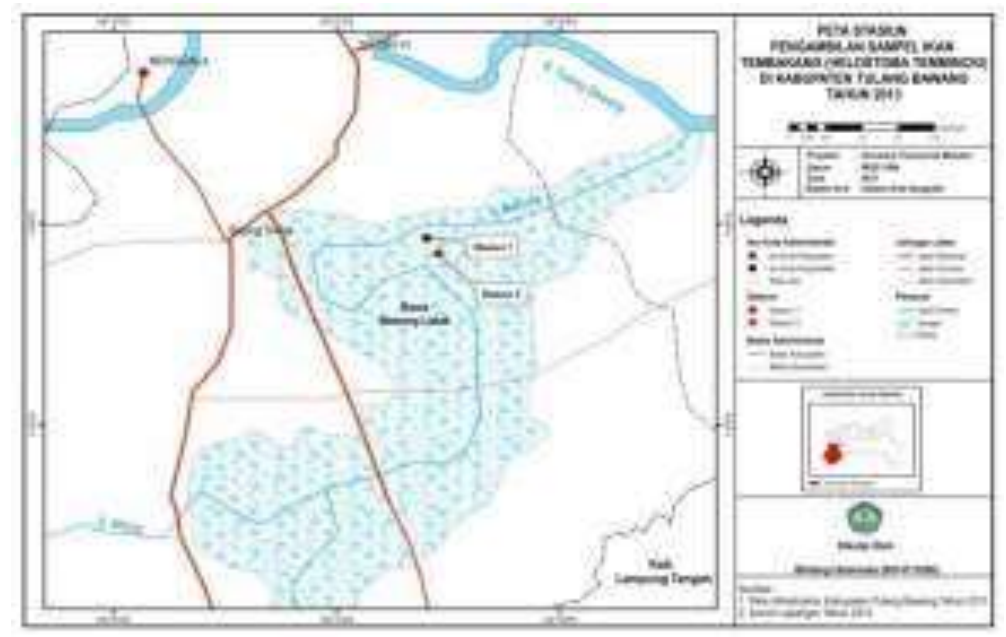

Gambar 1. Lokasi Penelitian

Alat yang digunakan dalam penelitian adalah penggaris (ketelitian $1 \mathrm{~mm}$ ), alat bedah, kertas label, alat tulis, mikroskop, GPS (global positioning system), neraca analitik dengan sensifitas 0,001 gram, botol sampel/plastik sampel, cool box, cawan petri, dan tisu. Bahan yang akan digunakan adalah ikan Tembakang (Helostoma temminckii) yang ditangkap dari Rawa Bawang Latak sebanyak 50 ekor/stasiun, aquades, dan larutan formalin 5\% dan $10 \%$.

Persiapan penelitian ini meliputi survey lokasi (penentuan tiap stasiun pengamatan), penentuan lokasi dilakukan dengan menentukan titik sampel (berdasarkan lokasi penangkapan ikan oleh nelayan setempat). Kemudian mengunduh koordinat titik sampel (stasiun pengamatan) menggunakan GPS. Menyiapkan alat dan bahan yang akan digunakan. Penentuan alat tangkap yang 
Bintang Ubamnata dkk: Kajian Pertumbuhan Ikan Tembakang (Helostoma temminckii) Di Rawa ...

digunakan. Dalam hal ini penentuan alat tangkap yang biasa digunakan oleh nelayan di sekitar Bawang Latak. Penentuan jumlah sampel 50 ekor/stasiun (berdasarkan kemampuan dan pengalaman peneliti).

Pelaksanaan penelitian ini meliputi Pengunduhan titik koordinat stasiun pengamatan dengan menggunakan GPS (global positioning system), dilakukan satu kali selama penelitian. Pengukuran kualitas air yang meliputi faktor fisika dan faktor kimia. Penangkapan ikan dilakukan dengan menggunakan alat tangkap sero, dengan mata jaring 0,5 inchi. Sero dipasang di rawa yang bagian permukaan airnya telah ditutupi oleh vegetasi yang lebat baik vegetasi yang terbentuk secara alami maupun buatan. Sero dipasang pada kedalaman antara 2 sampai 3 meter. Sero dipasang dengan sistem tancap. Karena sistem kerjanya ditancap yang membentang antara 30 sampai 50 meter dalam bentuk anak panah atau busur. Pada ujung busur disediakan ruang untuk menampung ikan. Pada pintu masuk ruang ini dibentuk sedemikian rupa sehingga ikan hanya bisa masuk tapi tidak bisa keluar. Sistem kerjanya sama seperti bubu. Sementara kaki busur yang terbuat dari deretan jaring membentang tegak lurus dari kaki hingga ujung busur, panjangnya bisa antara 30 sampai 50 meter, Fungsinya untuk menggiring ikan menuju ruangan yang telah disediakan. Pengangkutan dilakukan dengan cool box yang berisikan bongkahan es di dalamnya. Ikan sampel selanjutnya dibedah dan diamati di Laboratorium Budidaya Perikanan Universitas Lampung.

\section{HASIL DAN PEMBAHASAN}

\section{Kondisi Umum Rawa Bawang Latak}

Dari pengamatan di lapangan Rawa Bawang Latak terlihat memiliki aliran sungai yang tenang, dengan ditumbuhi vegetasi yang lebat, dengan warna perairan yang kecoklatan. Pada pinggiran perairan terdapat padang rumput, serta perakaran pepohonan.
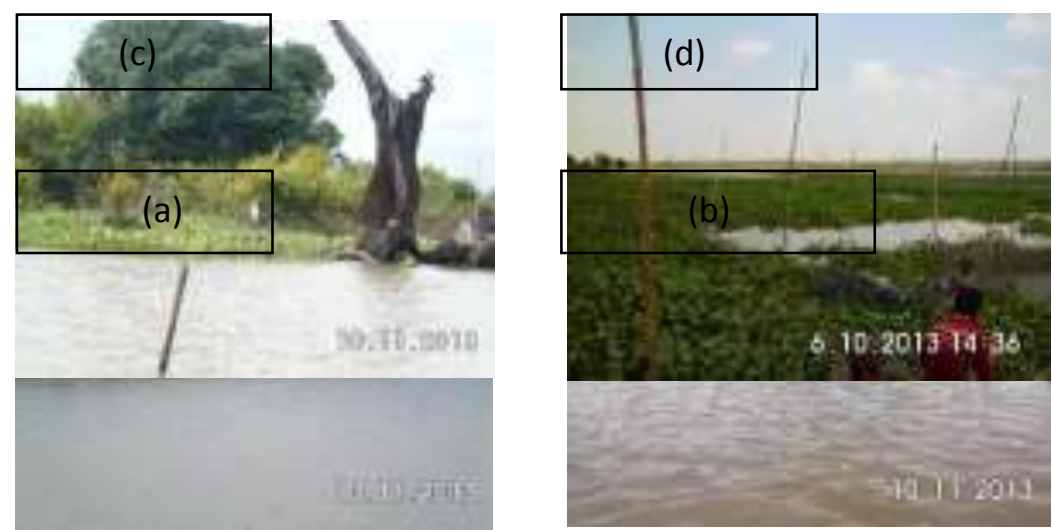

Gambar 2. Kondisi umum Rawa Bawang Latak (a) padang rumput di bagian Timur (b) perakaran tumbuhan di bagian Utara (c) vegetasi eceng gondok dan pepohonan di bagian Barat (d) vegetasi eceng gondok di bagian Selatan

Rawa Bawang Latak merupakan rawa banjiran yang mempunyai ciri khas fluktuasi air yang sangat berbeda antar waktu. Pada musim penghujan, air pada Rawa Bawang Latak mengalami kenaikan (Oktober-November), dan puncaknya pada bulan Desember. Pada bulan Desember sampai dengan Maret air akan mengalami fluktuasi, namun fluktuasinya kecil. Ketika musim penghujan air akan menggenangi hampir semua areal tanah kecuali daratan yang tinggi (talang), ketika musim 
kemarau air akan menjadi surut kecuali pada aliran sungai utama dan lebung, pada bulan April sampai dengan Mei permukaan air akan mengalami penyusutan dan mencapai fluktuasi terendah pada bulan Agustus sampai Oktober (Ondara, 1996), hal ini sesuai dengan pernyataan Welcome, (1985) bahwa rawa banjiran memiliki fluktuasi air yang berbeda, pada musim penghujan air akan menggenangi seluruh kawasan dataran yang rendah, pada musim kemarau air akan surut kecuali pada aliran sungai utama dan lebung rawa.

Rawa Bawang Latak memiliki tingkat produktivitas yang tinggi, dapat dilihat dari banyaknya kandungan bahan organik di dalamnya data kualitas air dapat dilihat pada. Kandungan bahan organik akan dimanfaatkan oleh detritus dan plankton sehingga menjadi makanan oleh ikan. Rawa banjiran dihuni berbagai jenis ikan yang memiliki produktivitas tinggi (Welcome, 1985). Jenis ikan tersebut secara garis besar dapat dikategorikan menjadi beberapa kelompok berdasarkan corak warna, yaitu kelompok ikan hitam (black fish) atau ikan yang mempunyai corak warna sisik gelap seperti gabus (Channa striata), sepat siam (Trichogaster pectoralis), betok (Anabas testudineus) dan lain-lain. Kelompok yang kedua adalah ikan putih (white fish) ikan yang memiliki corak warna sisik yang terang seperti lais (Cryptopterus spp), baung (Mystus nemurus), lampam (Puntius schwanefeldi) dan lain-lain. Pada musim kemarau kelompok ikan hitam umumnya menghuni perairan lebak yang tanahnya cekung dan dalam (lebung), sedangkan ikan putih terdapat pada perairan sungai.

Selain ikan, Rawa Bawang Latak dimanfaatkan oleh warga sekitar untuk bercocok tanam. Sumberdaya perairan sungai dan rawa banjiran dimanfaatkan oleh masyarakat untuk memenuhi berbagai kebutuhan, dapat berupa pemanfaatan di bidang pertanian seperti menanam padi, ketika perairan surut dan panen saat air kembali naik. Rawa Bawang Latak dialihfungsikan sebagai lahan pertanian oleh masyarakat pada saat air surut, pada saat air transisi dari tinggi ke rendah, lahan dimanfaatkan oleh masyarakat untuk menanam singkong.

Alat tangkap yang digunakan di Rawa Bawang Latak berupa sero, bubu, dan jala. Alat tangkap yang digunakan pada perairan sungai dan rawa banjiran adalah bersifat multy gears atau menggunakan banyak macam alat tangkap. Menurut Gaffar dan Utomo (1991), ada 11 jenis alat tangkap yang digunakan pada tipe perairan sungai dan rawa banjiran ini, antara lain yaitu tajur, rawai, empang, tuguk, kilung, sengkirai kawat, sengkirai bambu bilah, sengkirai rotan, kerakat, jala dan langgian.

\section{Kondisi Kualitas Air Rawa Bawang Latak}

Kandungan oksigen terlarut (DO) merupakan faktor pendukung optimal kehidupan organime perairan. Dari data kualitas air di atas, oksigen terlarut pada Rawa Bawang Latak berkisar antara 4,19$5,91 \mathrm{mg} / \mathrm{l}$, kondisi ini masih sesuai untuk kehidupan ikan tembakang, seperti apa yang dikemukakan oleh Utomo et al., (2010) yang menyatakan ikan tembakang dapat hidup pada kondisi perairan dengan DO yang relatif rendah (3-5 mg/L). Kandungan oksigen terlarut pada rawa banjiran pada musim kemarau dipengaruhi oleh beberapa faktor seperti ukuran badan air, stratifikasi, suhu, vegetasi perairan, plankton, proses dekomposisi bahan organik, dan difusi udara (Welcomme, 1979; Hartoto, 2000). Sitanggang (1987) mengemukakan bahwa ikan tambakan termasuk golongan ikan labyrinthici yaitu sebangsa ikan yang memiliki alat pernafasan berupa insang dan insang tambahan (labyrinth). Labyrinth adalah alat pernafasan yang berupa selaput tambahan yang berbentuk tonjolan pada tepi-tepi atas lapisan insang pertama. Pada selaput terdapat pembuluh darah kapiler (zat asam) langsung dari udara dan pernafasannya. Kandungan oksigen pada Rawa Bawang Latak cukup mampu mendukung kehidupan ikan tembakang. 
Bintang Ubamnata dkk: Kajian Pertumbuhan Ikan Tembakang (Helostoma temminckii) Di Rawa ...

Dari hasil pengamatan diperoleh kondisi kualitas air pada Rawa Bawang Latak dapat ditunjukkan pada tabel tabel 1.

Tabel 1. Kisaran parameter fisika kimiawi perairan pada daerah pengambilan sampel selama penelitian

\begin{tabular}{|c|c|c|c|c|c|c|c|c|c|}
\hline \multirow{3}{*}{ Parameter } & \multirow{3}{*}{ Satuan } & \multicolumn{8}{|c|}{ Hasil } \\
\hline & & \multicolumn{2}{|c|}{ Oktober } & \multicolumn{2}{|c|}{ November } & \multicolumn{2}{|c|}{ Desember } & \multicolumn{2}{|c|}{ Januari } \\
\hline & & ST 1 & ST 2 & ST 1 & ST 2 & ST 1 & ST 2 & ST 1 & ST 2 \\
\hline Arus & $\mathrm{m} / \mathrm{s}$ & 0 & 0 & 0 & 0 & - & - & - & - \\
\hline DO & $\mathrm{mg} / \mathrm{l}$ & 4,19 & 4,26 & 5,91 & 5,88 & - & - & - & - \\
\hline Suhu & 齊 & 31,2 & 31,2 & 29,3 & 29,4 & 30 & 30 & 28,7 & 28,9 \\
\hline Kecerahan & $\mathrm{cm}$ & 10 & 10 & 34 & 34 & 30 & 30 & 20 & 20,3 \\
\hline Kedalaman & $\mathrm{m}$ & 1,2 & 1,1 & 2,2 & 1,2 & 1,2 & 1 & 1,2 & 1 \\
\hline Amonium & & & & & & & & & \\
\hline$(\mathrm{NH} \Psi \equiv)$ & $\mathrm{mg} / \mathrm{l}$ & 2,485 & 2,025 & $>3,00$ & $>3,00$ & 0,33 & 0,12 & 0,24 & 0,12 \\
\hline Phospat (РО४) & $\mathrm{mg} / \mathrm{l}$ & 0,090 & 0,070 & 0,490 & 0,600 & 0,220 & 0,100 & 0,080 & 0,080 \\
\hline Total Bahan & & & & & & & & & \\
\hline Organik (TOM) & $\mathrm{mg} / \mathrm{l}$ & 39,18 & 38,55 & 29,704 & 17,7 & 17,06 & 11,38 & 31,6 & 44,24 \\
\hline TSS & $\mathrm{mg} / \mathrm{l}$ & 0,06 & 0,079 & 0,076 & 0,084 & 0,081 & 0,049 & 0,751 & 0,324 \\
\hline $\mathrm{pH}$ & - & 7,18 & 6,97 & 7,38 & 7,38 & 5,74 & 6,29 & - & - \\
\hline
\end{tabular}

Pada tabel 1, arus pada Rawa Bawang Latak memiliki nilai $0 \mathrm{~m} / \mathrm{s}$, ini menunjukkan perairan Bawang Latak memiliki aliran sungai yang tenang, sehingga Rawa Bawang Latak sesuai untuk kehidupan ikan tembakang. Hal ini sesuai dengan pernyataan Cuvier (1829), ikan tembakang dapat hidup dengan baik pada aliran sungai yang tenang.

Selama penelitian, kisaran nilai suhu pada Rawa Bawang Latak pada setiap lokasi/waktu berkisar antara $28,7-31,2^{\circ} \mathrm{C}$. Hasil pengamatan ini menunjukan bahwa terdapat perbedaaan suhu, ini diduga disebabkan oleh pergantian musim kemarau ke musim penghujan, yang pada saat musim kemarau suhu air lebih tinggi dibandingkan dengan suhu air pada musim penghujan. Seperti pernyataan Welcomme (1979) yang meyatakan bahwa intensitas cahaya, komposisi subtrat, kekeruhan, aliran air, air hujan, angin dan serta vegetasi yang lebat dan menutupi perairan dapat mempengaruhi suhu pada perairan sungai dan rawa banjiran. Daerah tropis memiliki kisaran suhu yang relatif stabil, yang baik untuk mendukung kehidupan organisme perairan yang berada pada kisaran 25-32 ${ }^{\circ} \mathrm{C}$ (Cholik et al., 1982 dalam Sinaga, 1995). Dari pernyataan tersebut dapat diketahui bahwa suhu di perairan Rawa Bawang Latak selama penelitian masih dapat mendukung proses biologi ikan organisme perairan.

Kecerahan pada Rawa Bawang Latak memiliki rentang variasi yang cukup besar yaitu berkisar 10-34 cm. Rendahnya penetrasi cahaya ke dalam kolom air ini diduga karena tingginya partikel tersuspensi, seperti hasil dekomposisi tanaman air dan detritus serta bahan organik yang terakumulasi dari vegetasi air yang terdapat pada rawa banjiran (Junk et al., 1989: de Carvalho et al., 2001). Hal ini dapat mempengaruhi DO pada perairan.

Pada data kedalaman air, dapat dilihat bahwa nilai tertinggi berada pada bulan November yaitu 2,2 meter, sedangkan terendah pada bulan Januari. Hal ini dipengaruhi oleh fluktuasi perairan yang berubah. Pada bulan November diduga pada malam hari sebelum pengambilan data terjadi hujan yang cukup lebat sehingga terjadi kenaikan air, sedangkan pada bulan Januari curah hujan berintensitas sedang.

Ammonium merupakan hasil dari denitrifikasi nitrat yang menghasilkan nitrogen bebas yang yang akan membentuk ammonium dan ammoniak melalui proses ammonifikasi nitrat. Rusmana 
(2003) menyatakan bahwa terdapat tiga proses reduksi nitrat disimilatif pada bakteri yaitu: denitrifikasi, reduksi nitrat menjadi amonium disimilatif, dan oksidasi amonium disimilatif (anaerob ammonia oxidation). Denitrifikasi adalah proses reduksi nitrat menjadi $\mathrm{N}_{2} \mathrm{O}$ atau $\mathrm{N}_{2}$. Pada proses ini bakteri menggunakan nitrat sebagai penerima elektron terakhir untuk memperoleh energi pada kondisi $\mathrm{O}_{2}$ terbatas atau anaerob (Ricardson et al., 2001). Proses reduksi nitrat ini sebagai penunjang pertumbuhan bakteri pada kondisi anaerob. Pada saat kondisi perairan normal ammonium akan teroksidasi menjadi nitrogen yang dapat membantu meningkatkan kesuburan perairan.

Fosfat pada Rawa Bawang Latak berkisar antara 0,07-0,60 mg/l, Fosfat digunakan oleh organisme untuk pertumbuhan dan sumber energi. Ortofosfat merupakan bentuk fosfor yang dapat dimanfaatkan secara langsung oleh tumbuhan akuatik, sedangkan polifosfat harus mengalami hidrolisis membentuk ortofosfat terlebih dahulu sebelum dapat dimanfaatkan sebagai sumber fosfat (Effendi, 2003). Silalahi (2009) menyatakan bahwa nilai ortofosfat 0,031 - 0,100 mg/l menunjukkan perairan yang subur/eutrofik. Umumnya kandungan fosfat dalam perairan alami sangat kecil dan tidak pernah melampui $0,1 \mathrm{mg} / \mathrm{l}$, kecuali bila ada penambahan dari luar oleh faktor antrogenik seperti dari sisa pakan ikan dan limbah pertanian (Tjahjo dan Purnamaninngtyas, 2008). Apridayanti (2008), menyatakan perairan yang oligotropik mempunyai kandungan ortofosfat $<0,01 \mathrm{mg} / \mathrm{l}$, mesotrofik 0,01 $0,05 \mathrm{mg} / \mathrm{l}$, eutrofik $>0,1 \mathrm{mg} / \mathrm{l}$. Dalam hal ini perairan rawa Bawang Latak merupakan tipe perairan eutrofik.

Bahan organik total atau total organic matter (TOM) menggambarkan jumlah bahan organik suatu perairan yang terdiri dari bahan organik terlarut, bahan organik tersuspensi. Berdasarkan data analisis laboratorium bahan organik total (TOM) berkisar antara 11,38-44,24 mg/l. Bahan organik ini berasal dari sisa fesses, tumbuhan yang mati, bangkai ikan dan masih banyak yang lain. Pada bulan desember total bahan organik perairan mengalami penurunan ini diduga karena pergerakan masa air pada saat perairan mulai meninggi, sehingga bahan-bahan organik tersuspensi yang belum turun menjadi sedimen mengalami pergerakan mengikuti arah arus air.

Nilai pH perairan selama penelitian berkisar antara 5,74-7,38 yang berarti perairan asam. Hal ini diduga disebabkan adanya asam humat yang dapat dicirikan dengan warna perairan coklat tua hingga kehitaman oleh sebab itu rawa banjiran dikenal sebagai perairan hitam. Hal ini sama dengan pernyataan Cuvier (1928) yang menyatakan bahwa ikan tembakang hidup pada $\mathrm{pH}$ kisaran 6-8.

\section{Aspek Pertumbuhan}

\section{Hubungan Panjang dan Berat}

Pengamatan hubungan panjang berat dilakukan dengan mengamati sampel sebanyak 100 sampel yang terdiri dari dua stasiun pengamatan. Berikut adalah tabel hubungan panjang berat ikan tembakang, yang ditangkap di perairan Rawa Bawang Latak.

Tabel 2. Hubungan panjang berat ikan tembakang (Helostoma temminckii) yang tertangkap di Rawa Bawang Latak selama penelitian

\begin{tabular}{|c|c|c|c|c|c|}
\hline \multirow{2}{*}{ Bulan } & \multicolumn{4}{|c|}{ Parameter } & \multirow[b]{2}{*}{ Pola pertumbuhan } \\
\hline & $\mathrm{W}$ & A & $\mathrm{B}$ & $\mathrm{R}^{2}$ & \\
\hline Oktober & $y=0,074 x^{4,146}$ & 0,074 & 4,146 & 0,906 & Allometri Positif \\
\hline November & $y=0,128 x^{3,418}$ & 0,128 & 3,418 & 0,709 & Allometri Positif \\
\hline Desember & $y=0,213 x^{2,793}$ & 0,213 & 2,793 & 0,749 & Allometri Negatif \\
\hline Januari & $y=0,117 x^{3,572}$ & 0,117 & 3,572 & 0,865 & Allometri Positif \\
\hline
\end{tabular}


Bintang Ubamnata dkk: Kajian Pertumbuhan Ikan Tembakang (Helostoma temminckii) Di Rawa ...

Jika dilihat pada tabel 2 nilai $\mathrm{b}$ per bulan adalah $>3$ yang artinya pertumbuhan bersifat allometri positif, artinya pertumbuhan berat lebih dominan dari pertumbuhan panjang tubuh ikan. Pada bulan Desember pertumbuhan bersifat allometri negatif, dimana nilai $b<3$ yang artinya pertumbuhan panjang lebih dominan dari berat tubuh ikan, ini dikarenakan pada bulan Desember total bahan organik menurun yang mengakibatkan ketersediaan makanan sedikit sehingga pertumbuhan terhambat. Nikolsky (1963) menyatakan bahwa pola pertumbuhan organisme perairan bervariasi, hal ini tergantung pada kondisi lingkungan tempat organisme tersebut berada dan ketersediaan makanan, yang dimanfaatkan untuk menunjang kelangsungan hidup dan pertumbuhannya. Effendi (1979) juga menyatakan bahwa perbedaan nilai b secara biologis berhubungan dengan kondisi ikan, namun kondisi ikan juga dipengaruhi oeh makanan, umur, jenis kelamin dan tingkat kematangan gonad.

Pada bulan Desember $\mathrm{pH}$ menunjukkan rata-rata 5-6 yang berarti bersifat asam, ini dikarenakan pada bulan Desember terjadi curah hujan yang cukup tinggi. Pada kondisi $\mathrm{pH}$ asam ikan akan sedikit mengalami gangguan untuk pertumbuhan (Kordi dan Tancung, 2007), pada kondisi perairan yang bersifat asam, ikan akan mengalami gangguan metabolisme. Kordi dan Tancung (2007), menyatakan bahwa dalam budidaya pada pH 5 masih dapat ditolerir oleh ikan tapi pertumbuhan ikan akan terhambat. Selain $\mathrm{pH}$ total bahan organik pada bulan November mengalami penurunan, bahkan dari empat bulan pengamatan, bulan Desember memiliki total bahan organik paling rendah yaitu 11-17 mg/l. Bahan organik merupakan bahan yang dimanfaatkan oleh ikan tembakang sebagai makanannya.

Dari data pada tabel 3 dapat diketahui bahwa nilai koefisien korelasi (r) yang mendekati nilai satu yaitu antara 0,709-0,906. Menurut Walpole (1995) apabila nilai koefisien korelasi (r) mendekati nilai 1 atau -1 maka terdapat hubungan linear antara pertumbuhan berat dan pertumbuhan panjang ikan.

\section{Faktor Kondisi}

Setelah nilai hubungan panjang dan berat diketahui, maka dapat diketahui juga nilai faktor kondisi ikan tembakang. Faktor kondisi merupakan keadaan atau kemontokan ikan yang dinyatakan dengan angka berdasarkan data hubungan panjang berat.

Tabel 3. Faktor kondisi berdasarkan selang kelas ikan tembakang (Helostoma temminckii) yang tertangkap di Rawa Bawang Latak selama penelitian

\begin{tabular}{ccc}
\hline \multirow{2}{*}{ Selang kelas panjang Ikan } & \multicolumn{2}{c}{ Faktor Kondisi (Kn) } \\
\cline { 2 - 3 } & Jantan & Betina \\
\hline $120-128$ & 1,315 & 0,966 \\
$129-137$ & 1,119 & 0,977 \\
$138-146$ & 1,031 & 1,011 \\
$147-155$ & 0,895 & 1,023 \\
$156-164$ & 0,875 & 0,972 \\
$165-173$ & 0,755 & 0,953 \\
\hline
\end{tabular}

Setelah dilakukan pengolahan data statistik maka nilai faktor kondisi sudah dapat tersaji pada tabel 3. Jika dilihat dari tabel 3, ikan dibagi menjadi 6 kelompok berdasarkan selang kelas panjang ikan. Secara umum dapat kita ketahui bahwa faktor kondisi $(\mathrm{Kn})$ memiliki nilai $<1$, namun pada selang kelas jantan 120-128, 129-137 dan 138-146, memiliki nilai faktor kondisi (Kn) > 1, sedangkan pada betina terdapat pada selang kelas 138-146 dan 147-155. Hal ini diduga disebabkan oleh perbedaan tingkat kematangan gonad dan jenis kelaminikan tembakang, hal ini sesuai dengan pernyataan Effendie (1997) faktor kondisi (Kn) dipengaruhi oleh kematangan gonad dan jenis kelamin ikan. 
Jurnal Penelitian Pertanian Terapan

Tabel 4. Faktor kondisi berdasarkan waktu pengambilan sampel ikan tembakang (Helostoma temminckii) yang tertangkap di Rawa Bawang Latak selama penelitian

\begin{tabular}{ccc}
\hline \multirow{2}{*}{ Bulan } & \multicolumn{2}{c}{ Faktor Kondisi (Kn) } \\
\cline { 2 - 3 } & Jantan & Betina \\
\hline Oktober & 0,999 & 0,976 \\
November & 1,005 & 1,016 \\
Desember & 1,022 & 1,009 \\
\hline
\end{tabular}

Tabel di atas menunjukkan faktor kondisi $(\mathrm{Kn})$ berdasarkan waktu pengamatan di Rawa Bawang Latak. Dapat kita lihat pada tabel di atas bahwa nilai faktor kondisi (Kn) jantan dan betina ikan tembakang secara umum memiliki nilai > 1, namun pada bulan Oktober faktor kondisi (Kn) memiliki nilai $<1$. Ini diduga pada bulan November dan Desember ikan tembakang menggunakan energinya untuk pertumbuhan setelah melakukan pemijahan, yang berarti bahwa pada bulan Oktober menuju bulan November terjadi pemijahan, dan berakhir pada pertengahan bulan November menuju Desember. Menurut Effendie (1979) bahwa variasi dalam faktor kondisi bergantung pada kepadatan populasi, tingkat kematangan gonad, makanan, jenis kelamin, dan umur.

\section{Parameter Pertumbuhan (K dan $L \infty)$ dan $\mathbf{t}_{0}$}

Parameter pertumbuhan von Bertalanffy ( $\mathrm{K}$ dan $\mathrm{L} \infty$ ) dapat diketahui dengan menganalisis serangkaian data frekuensi panjang menggunakan metode ELEFAN I yang terdapat pada perangkat lunak FISAT II (Gayanilo et al. 2005). Selanjutnya untuk menghitung nilai $t_{0}$ dapat dilakukan dengan memasukkan nilai K dan L $\infty$ yang sudah diperoleh menggunakan persamaan menurut Pauly (1979), yaitu $\log \left(-\mathrm{t}_{\mathrm{o}}\right)=-0,3922-0,2752 \log \mathrm{L} \infty-1,038 \log \mathrm{K}$.

Tabel 5. Parameter pertumbuhan $(\mathrm{L} \infty, \mathrm{K})$ dan $\mathrm{t}_{0}$ ikan tembakang (Helostoma temminckii) yang tertangkap di Rawa Bawang Latak

\begin{tabular}{lrcc}
\hline \multirow{2}{*}{ Sampel Ikan } & \multicolumn{3}{c}{ Parameter Pertumbuhan } \\
\cline { 2 - 4 } & $\mathrm{K}$ (pertahun) & $\mathrm{L} \infty(\mathrm{mm})$ & $\mathrm{t}_{0}$ (tahun) \\
\hline Jantan & 0,47 & 180,6 & $-0,21$ \\
Betina & 0,96 & 191,1 & $-0,099$ \\
\hline
\end{tabular}

Berdasarkan analisa parameter pertumbuhan ( $\infty \infty$ dan $\mathrm{K}$ ) dengan menggunakan metode ELEFAN 1 dalam program FiSAT II, dan penghitungan secara langsung nilai $\mathrm{t}_{0}$, diketahui persamaan Von Bartalanffy untuk ikan tembakang jantan adalah $\mathrm{Lt}=180,6^{*}[1-\mathrm{e}-0,47(\mathrm{t}+0,21)]$ ini berarti ikan tembakang jantan diduga mulai matang gonad pada umur 21 bulan sedangkan betina adalah $\mathrm{Lt}=$ $191,1 *$ [1-e-0,96(t+0,09963)] ini berarti ikan tembakang betina diduga mulai matang gonad pada umur 8 bulan. Pada tabel terlihat nilai koefisien betina lebih tinggi dibanding dengan jantan ini berarti nilai pertumbuhan ikan betina lebih cepat dibanding jantan dalam mendekati L $\infty$. Hal ini diduga karena beberapa faktor internal seperti faktor genetik,umur dan perbedaan ukuran ikan, sedangkan faktor eksternal seperti jumlah makanan intensitas penangkapan serta lingkungan perairan. Nikolsky (1969) menyatakan perbedaan pertumbuhan ikan dipengaruhi oleh beberapa faktor seperti intensitas penangkapan, ketersediaan makanan, dan faktor abiotik yang mempengaruhi kesuburan perairan. 
Bintang Ubamnata dkk: Kajian Pertumbuhan Ikan Tembakang (Helostoma temminckii) Di Rawa ...

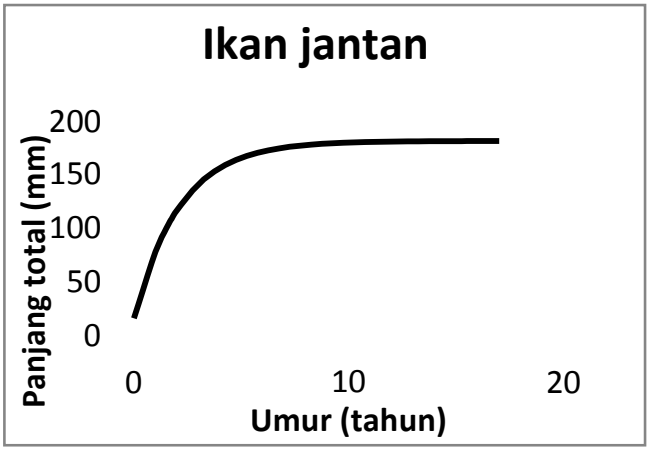

(a)

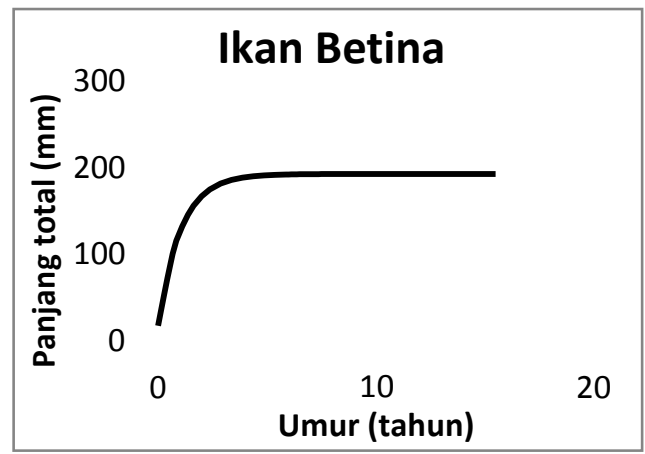

(b)

Gambar 3. Grafik pertumbuhan ikan tembakang (Helostoma temminckii) (a) jantan (b) betina yang tertangkap di Rawa Bawang Latak selama penelitian

Gambar 3 menunjukkan bahwa ikan tembakang muda akan mengalami laju pertumbuhan yang cepat hingga menuju dewasa, namun disaat ikan dewasa laju pertumbuhan akan mengalami perlambatan. Ikan tembakang akan terus mengalami pertumbuhan panjang walaupun pada keadaan perairan yang tidak mendukung pertumbuhan ikan. Peningkatan ukuran panjang umumnya tetap berlangsung walaupun ikan mungkin dalam keadaan kekurangan makanan (Busacker et al., 1990 dalam Harmiyati 2009).

\section{KESIMPULAN}

Pola pertumbuhan ikan tembakang positif, nilai-nilai faktor kondisi ikan jantan dan betina alometrik tidak berbeda secara signifikan, ikan tembakang betina pertumbuhan lebih cepat dari ikan jantan, jantan tembakang ikan pada ukuran 180,6 mm adalah 21 bulan, sedangkan betina dalam ukuran $191,1 \mathrm{~mm}$ berusia 8 bulan

\section{DAFTAR PUSTAKA}

Apridayanti E. 2008. Evaluasi Pengelolaan Lingkungan Perairan Waduk Lahor Kapubaten Malang Jawa Timur. [Tesis] Universitas Diponegoro

Anonim. 2011. Kajian Usulan Kawasan Reservat Ikan Air Tawar Di Kabupaten Tulang Bawang. Fakultas Pertanian. [Proposal] Universitas Lampung: Bandar Lampung

Cuvier. 1829. Helostoma temminkii. http://www.fishbase.org/ summary/ Helostoma -temminkii. html [3 November 2012 pukul 00.00 WIB]

De Carvalho P, Bini LM, Thomaz SM, de Oliveira LG, Robertson B, Tavechio WLG, and Darwisch AJ. 2001. Comparative limnology of South American Floodplain Lakes and Lagoons. Acta Scientiarum Maringa XXIII (2):265-273

Effendie MI. 1997. Biologi perikanan. Yayasan Pustaka Nusatama. Yogyakarta. 157 hal.

Effendi, Hefni. 2003. Telaah Kualitas Air. Kanisius. Yogyakarta.

Effendie MI. 1979. Metode biologi perikanan. Yayasan Dewi Sri. Bogor. 112 hal. 
Gayanilo FC Jr, Sparre P, Pauly D. 2005. FAO-ICLARM Stock Assessment Tools II (FISAT II). Revised version. User's guide. FAO Computerized Information Series (Fisheries) No.8. Rome: FAO. hlm. 52-53, 97-98.

Harmiyati, Desi. 2009. Analisis hasil tangkapan sumberdaya ikan ekor kuning (Caesio cuning) yang didaratkan di PPI Pulau Pramuka, Kepulauan Seribu. Skripsi. Manajemen Sumberdaya Perikanan. Fakultas Perikanan dan Ilmu Kelautan. Institut Pertanian Bogor

Hartoto, D.I. 2000. Relatoinship of Water Level to Water Quality in an of Oxbow lake of Central Kalimantan. Proceedings of the Internatoinal Symposium on: Tropical Peat Lands Bogor. Indonesia

Kordi, M.G.H. dan A.B. Tancung. 2007. Pengelolaan Kualitas Air. PT Rineka Cipta, Jakarta

Nikolsky G.V. 1963. The Ecology of Fishes. Academic Press. New York. 325 hal.

Pauly D. 1979. Theory and management of tropical multispecies stocks: A review, with emphasis on the Southeast Asian demersal fisheries. ICLARM Studies and Reviews No. 1. Manila: International Center for Living Aquatic Resources Management. Hlm

Rusmana I. 2003. Reduksi Nitrat Disimilatif Pada Bakteri: Isu Lingkungan dan Penerapannya. Jurnal Hayati (4): 158-160.

Silalahi, J. 2009. Analisis Kualitas Air dan Hubungannya dengan Keanekaragaman Vegetasi Akuatik di Perairan Balige Danau Toba. [Tesis] Universitas Sumatera Utara. 100 hal

Sinaga TP. 1995. Bioekologi Komunitas Ikan di Sungai Banjaran Kabupaten Banyumas, Jawa Tengah. [tesis]. Program Pascasarjana Institut Pertanian Bogor. Bogor.

Tjahjo D W H dan Purnamaningtyas S E. 2008. Kajian Kualita air dalam Pengembangan Perikanan di Waduk Ir. H. Djuanda, Jawa Barat. Jurnal Lit. Perikanan Indonesia XVI. (1) : 15-29

Walpole RE. 1995. Pengantar statistika, Edisi ke-3. Gramedia Pustaka Utama. Jakarta. 515 hlm. Welcomme, RL. 1979: Fisheries Ecology of Floodplain rivers. Longman, london: 317 pp.

Welcomme, RL. 1979: Fisheries Ecology of Floodplain rivers. Longman, london: 317 pp. 